\title{
KADAR ALBUMIN IBU HAMIL DITINJAU DARI PENGETAHUAN DAN TINDAKAN TENTANG GIZI DI WILAYAH KERJA PUSKESMAS MANDALA MEDAN
}

\author{
Ginta Siahaan \\ Dosen Jurusan Gizi Poltekkes Kemenkes Medan
}

\begin{abstract}
Pregnancy is a thing in life that can create a happy family, where there will be physical and mental changes that are naturally (Sigalingging, 2009). Nutritional problems that are often experienced by pregnant women is less Chronic Energy (KEK) and nutrition anemia. Cake during pregnancy will restrict fetal growth and risk BBLR. One of the parameters to determine the cake on the pregnant mother is to perform an examination of albumin. The low nutrient intake especially protein consumed during pregnancy as causes of nutrition disorders can be seen from the level of albumin blood pregnant. The trigger factor of lack of knowledge about nutrition and disregarding the pregnant mother to the condition of the pregnancy progresses, among others economic status level of education which is still very low and pregnancy at a young age. Maternal Nutrition knowledge is low, usually not followed by the action of good mothers to meet the nutrition intake during pregnancy progresses (Bahar, 2013). The general aim of this research is to know the relation of knowledge and action on nutrition with serum albumin pregnant in the working area of the Puskesmas Mandala Medan. This research is cohort studies with Cross Sectional design and data analyzed using the Chi Square Test to know the relation of knowledge and action on nutrition with serum albumin on the pregnant mother in the working area of the Puskesmas Mandala Medan. The results of the study showed that there are significant relationships between nutrition knowledge with serum albumin pregnant, and no significant relationships between the actions with serum albumin pregnant.
\end{abstract}

Keywords : Knowledge, Actions, Albumin, Pregnant

\section{Pendahuluan}

Dalam siklus kehidupan manusia pertumbuhan tercepat terjadi pada beberapa periode, yaitu pada masa janin dan berlanjut hingga usia dua tahun serta pada masa remaja. Istilah 1000 hari pertama kehidupan, yaitu 270 hari selama kehamilan dan 730 hari dari kelahiran sampai usia 2 tahun. Dalam rangka meningkatkan Sumber Daya Manusia Indonesia, pemerintah membuat program Gerakan Nasional Sadar Gizi dalam Rangka Percepatan Perbaikan Gizi pada 1000 Hari Pertama Kehidupan yang bertujuan untuk menanggulangi masalah stunting dan efek untuk dikehidupan mendatang. Ibu hamil merupakan salah satu kelompok sasaran dalam gerakan kehidupan 1000 hari pertama manusia (Menkokesra, 2012).

Kehamilan merupakan suatu hal dalam kehidupan yang dapat membuat keluarga bahagia, dimana akan terjadi perubahan fisik dan mental yang bersifat alami. Para calon ibu harus sehat dan mempunyai berat badan normal sebelum hamil dan setelah hamil, mengonsumsi makanan yang bergizi, teratur berolahraga serta menghindari kebiasaan merokok. Seorang ibu hamil, perlu untuk menjaga pertumbuhan dan perkembangan janinnya dengan baik, yang didukung oleh asupan zat gizi yang adekuat. Asupan zat gizi dapat terpenuhi dengan baik bila mengonsumsi makanan yang sehat dan seimbang yang mengandung unsur-unsur zat gizi yang cukup (Sigalingging, 2009).

Permasalahan gizi yang sering dialami oleh ibu hamil adalah Kurang Energi Kronik (KEK) dan anemia gizi. KEK pada saat hamil akan menghambat pertumbuhan janin sehingga menimbulkan resiko BBLR. Hasil Riskesdas tahun 2007, angka prevalensi risiko KEK pada ibu hamil di Indonesia sebesar 13,6\%, di Sumatera Utara $7,9 \%$. KEK pada ibu hamil dapat disebabkan karena ketidakseimbangan asupan gizi dan penyakit infeksi. Keadaan diatas diperkuat oleh data Riskesdas 2010, yang menyatakan secara nasional terdapat $44,8 \%$ ibu hamil mengkonsumsi energi dibawah kebutuhan minimal. Sedangkan untuk persentase ibu hamil yang mengkonsumsi protein di bawah kebutuhan minimal sebesar $49,5 \%$.

Salah satu parameter untuk menentukan KEK pada ibu hamil adalah dengan melakukan pemeriksaan albumin. Rendahnya asupan zat gizi terutama protein yang dikonsumsi selama masa kehamilan sebagai penyebab terjadinya gangguan gizi dapat dilihat dari kadar albumin darah ibu hamil. Albumin merupakan protein terbanyak dalam plasma, sekitar $60 \%$ dari total plasma protein. Selama masa kehamilan, albumin berfungsi untuk membawa sari-sari makanan melalui plasenta untuk perkembangan janin serta bermanfaat dalam pembentukan 
jaringan sel baru. Pembentukan jaringan sel yang baru dibutuhkan pada saat pertumbuhan bayi selama dalam kandungan. Albumin juga berfungsi dalam pengikatan dan pengangkutan senyawa endogen dan eksogen termasuk zat-zat gizi. Selain itu albumin juga dapat berfungsi sebagai prediktor terjadinya preeklampsia pada masa kehamilan, yang ditandai dengan adanya odema (Murray dkk, 2009).

Rossi dalam penelitiannya tahun 2013, menyatakan ada korelasi positif antara albumin terhadap aktifitas protrombin yang berfungsi dalam proses pembekuan yang dibutuhkan pada saat partus. Artinya semakin rendah kadar albumin maka proses pembekuan darah tidak terjadi, mengakibatkan perdarahan. Kemudian dijelaskan dalam penelitian Nugroho (2013) yang menyebutkan bahwa albumin dalam tubuh disintesa di dalam hati dengan jumlah sangat kecil. Rendahnya kadar albumin darah selama masa kehamilan dikhawatirkan dapat memicu terjadinya masalah KEK yang dapat membahayakan perkembangan janin dalam kandungan.

Pemenuhan asupan gizi pada ibu hamil dipengaruhi oleh berbagai faktor seperti faktor sosial, ekonomi, dan pengetahuan ibu hamil tentang gizi untuk ibu dan janin yang dikandungnya. Ibu hamil yang memiliki pengetahuan gizi yang baik akan mampu memilih jenis makanan yang tepat untuk dirinya dan janinnya baik dari segi kuantitas maupun kualitas. Selain pengetahuan gizi, pengetahuan kesehatan kehamilan juga perlu bagi ibu hamil. Dengan demikian pengetahuan gizi dan kesehatan merupakan salah satu faktor protektif dalam mempertahankan kualitas kehamilan beserta janin yang akan dilahirkan (Rahmaniar, 2011).

Hasil penelitian Surasih (2005) menyatakan salah satu penyebab munculnya gangguan gizi adalah kurangnya pengetahuan tentang gizi pada masa kehamilan. Penelitian yang dilakukan Surasih sejalan dengan penelitian yang dilakukan oleh Rahmaniar (2007) menunjukkan adanya hubungan tingkat pengetahuan dengan kejadian KEK pada ibu hamil yaitu dari 32 ibu hamil yang memiliki pengetahuan kurang, terdapat 6 orang $(18,8 \%)$ yang menderita KEK, dan dari 28 ibu yang memiliki pengetahuan cukup, 15 orang $(53,6 \%)$ diantaranya menderita KEK (Sigalingging, 2009).

Faktor pemicu kurangnya pengetahuan tentang gizi serta ketidakpedulian ibu hamil terhadap kondisi kehamilannya, antara lain status ekonomi, tingkat pendidikan yang masih rendah, serta kehamilan di usia muda. Pengetahuan gizi ibu hamil yang rendah, biasanya tidak diikuti oleh tindakan ibu yang baik untuk memenuhi asupan nutrisi selama masa kehamilannya. Menurut Sunarto (2004) munculnya tindakan sadar gizi didukung oleh adanya pengetahuan gizi ibu hamil yang baik serta motivasi dan niat yang kuat dari diri sendiri sehingga ibu hamil akan berbuat sesuatu untuk memenuhi asupan zat gizi dan kesehatan selama masa kehamilan (Bahar, 2013).

Berdasarkan data hasil PBL PSG oleh mahasiswa semester III Jurusan Gizi Poltekkes Kemenkes Medan pada tanggal 24 - 26 November 2014 dan ditindaklanjuti dengan hasil observasi penulis pada tanggal tanggal 2 dan 13 Desember 2014 di Wilayah Kerja Puskesmas Mandala Medan diketahui bahwa terdapat \pm 59 ibu hamil. Dari uraian latar belakang diatas, penulis tertarik untuk melakukan penelitian "Hubungan pengetahuan dan tindakan tentang gizi dengan kadar albumin ibu hamil di Wilayah Kerja Puskesmas Mandala Medan"

\section{Metode Penelitian}

Jenis penelitian ini bersifat Observasional dengan desain Cross Sectional untuk mengetahui hubungan pengetahuan dan tindakan tentang gizi dengan kadar albumin ibu hamil penerima BPJS GAKIN di Wilayah Kerja Puskesmas Mandala Medan dalam kurun waktu dan penelitian yang sama (Siagian, 2010).Penelitian ini telah dilaksanakan di Wilayah Kerja Puskesmas Mandala Medan.

Populasi dalam penelitian ini adalah seluruh ibu hamil yang merupakan penerima BPJS GAKIN yang bertempat tinggal di Wilayah Kerja Puskesmas Mandala Medan, yaitu di Kelurahan Bantan dan Kelurahan Tembung yang berjumlah 59 orang.

Dalam penelitian yang akan dilaksanakan ini seluruh populasi akan dijadikan sampel yang disebut total sampling, kemudian dilakukan screening sesuai kriteria inklusi seperti di bawah ini :

a. Ibu hamil yang tinggal di Wilayah Kerja Puskesmas Mandala Medan

b. Ibu hamil penerima BPJS GAKIN di Wilayah Kerja Puskesmas Mandala Medan

c. Umur ibu pada saat hamil adalah 20-35 tahun

d. Usia kehamilan ibu 1-7 bulan

e. Bersedia menjadi sampel dan mau diteliti

f. Tidak dalam keadaan sakit menurut diagnosa bidan

g. Ibu hamil tidak mengalami komplikasi dalam kehamilannya

h. Dapat diajak berkomunikasi dengan baik Dengan melihat kriteria tersebut diatas maka sampel yang diteliti berjumlah 53 ibu hamil.

Pada saat penelitian, jenis data yang dikumpulkan meliputi data primer dan data sekunder. Melalui prosedur yang telah ditentukan maka akan diperoleh berbagai jenis data yang diinginkan oleh peneliti, meliputi :

1. Data primer

a. Data identitas sampel meliputi : nama, umur, usia kehamilan dan alamat, diperoleh dari wawancara secara langsung dengan mengisi form identitas sampel.

b. Data pengetahuan gizi ibu hamil yang diperoleh dari wawancara secara langsung dengan menggunakan form kuesioner.

c. Data tindakan gizi ibu hamil yang diperoleh dari wawancara secara langsung dengan menggunakan form kuesioner dan diperkuat dengan pengamatan secara langsung dengan mengisi form pengamatan tindakan.

d. Data kadar albumin darah

Data kadar albumin darah diperolehdengan dengan melakukan pengambilan darah sampel melalui jarum suntik yang ditusukkan kedalam pembuluh darah dibagian lengan dengan menggunakan metode Brom Cresol Green (BCG) 
dengan alat spektrofotometri. Pengambilan darah dilakukan oleh tenaga paramedis, kemudian darah dimasukkan ke dalam tabung reaksi yang sudah diberi antikoagulan kemudian dibawa ke laboratorium. Adapun setiap sampel diambil darahnya sebanyak 2 cc untuk diperiksa (Supariasa, 2008).

Prosedur pemeriksaan kadar albumin darah adalah sebagai berikut:

i. Darah sampel diambil melalui pembuluh darah dilengan.

ii. Masukkan darah dalam tabung kemudian dicentrifuge selama 10 menit dengan kecepatan $3000 \mathrm{rpm}$. (untuk memisahkan antara plasma darah dan serumnya).

iii. Setelah serum didapat, kemudian dimasukkan ke dalam tabung reaksi yang bersih dan kering.

iv. Lalu ambil serum sebanyak $10 \mu \mathrm{l}$ dan ditambahkan reagen warna sebanyak $1000 \mu 1$. Kemudian diaduk dan diinkubasi selama 5 menit pada suhu $25^{\circ} \mathrm{C}$, dilakukan sebanyak 3 kali.

v. Campurkan standard sebanyak $10 \mu \mathrm{l}$ dan reagen warna sebanyak $1000 \mu$ l. Kemudian diaduk dan diinkubasi selama 5 menit pada suhu $25^{\circ} \mathrm{C}$, dilakukan sebanyak 3 kali (larutan standar ini digunakan sebagai pembanding bagi sampel).

vi. Lakukan hal yang sama untuk blanko 1000 $\mu 1$.

vii. Ukur absorban sampel dan standard terhadap blanko dengan panjang gelombang $\mathrm{Hg} 546 \mathrm{~nm}$, program C/ST, faktor 4 gr/dl (Khanifah, 2009).

2. Data Sekunder

Data yang dikumpulkan meliputi data gambaran umum kelurahan, data-data ibu hamil penerima BPJS GAKIN, yang diperoleh dari petugas posyandu ibu hamil, kader PKK, dan TPG yang bertugas di Puskesmas Mandala.

Data - data yang akan diolah meliputi:

$\checkmark$ Data pengetahuan gizi ibu hamil yang dikumpulkan dengan metode wawancara dengan alat bantu kuesioner sebanyak 28 pertanyaan yang skor tertingginya 3 dan terendahnya 1 yang akan dijumlahkan dari seluruh itempertanyaan, denganmenggunakan rumus :

$=\frac{\text { TotalSkorTertinggi }- \text { TotalSkorTerendah }}{\text { Kategori }}$

$=\frac{84-28}{3}$

$=18,67 \approx 19($ Kelas Interval $)$

Kemudian dikategorikan berdasarkan jumlah skor yang diperoleh menjadi 3 kategori, yaitu :

a. Pengetahuan Baik : skor $65-84$

b. Pengetahuan Cukup: skor $46-64$

c. Pengetahuan Kurang: skor $<46$

$\checkmark \quad$ Data tindakan gizi ibu hamil yang dikumpulkan dengan metode wawancara dan pengamatan langsung dengan alat bantu kuesioner sebanyak 15 pertanyaan yang skor tertingginya adalah 3 dan terendahnya adalah 1 serta diperkuat dengan mengisi form pengamatan tindakan kemudian dijumlahkan dari seluruh item pertanyaan, dengan menggunakan rumus :

$$
\begin{aligned}
&= \frac{\text { TotalSkorTertinggi }- \text { TotalSkorTerendah }}{\text { Kategori }} \\
&= \frac{45-15}{3} \\
&=10 \text { (Kelas Interval) }
\end{aligned}
$$

Kemudian dikategorikan berdasarkan jumlah skor yang diperoleh menjadi 3 kategori, yaitu :

$\begin{array}{lll}\text { a. } & \text { Baik } & \text { : skor } 35-45 \\ \text { b. } & \text { Cukup } & \text { : skor } 25-34 \\ \text { c. } & \text { Kurang } & \text { : skor }<25\end{array}$

$\checkmark \quad$ Data kadar albumin diolah secara manual dengan melihat standar baku pemeriksaan kadar albumin darah, berdasarkan hasil pemeriksaan dengan menggunakan metode Brom Cresol Green (BCG) dengan alat spektrofotometer (Khanifah, 2009).Data albumin darah yang sudah diperiksa kemudian dikategorikan menjadi 2, yaitu:

a. Normal bila : 3,2-5,2 g/dL

b. Tidak normal bila : $<3,2 \mathrm{~g} / \mathrm{dL}$

Data yang sudah didapat dan diolah dengan menggunakan program SPSS kemudian dianalisis berdasarkan variabel :

$\checkmark$ Analisis univariat, dilakukan untuk mendeskripsikan berbagai variabel yang diteliti dengan menggunakan tabel distribusi frekuensi menggunakan program SPSS dan disajikan dalam grafik distribusi frekuensi serta dianalisis berdasarkan presentase.

$\checkmark$ Analisis bivariat untuk melihat hubungan pengetahuan dan tindakan tentang gizi dengan kadar albumin darah ibu hamil penerima BPJS GAKIN di Wilayah Kerja Puskesmas Mandala Medan yaitu dengan menggunakan bantuan komputerisasi dengan program SPSS, kemudian dilanjutkmenggunakan uji chi square dengan mengambil kesimpulan berdasarkan signifikan, jika nilai $\mathrm{p}<0,05$ maka Ho di tolak maka ada hubungan pengetahuan dan tindakan tentang gizi dengan kadar albumin ibu hamil penerima BPJS GAKIN di Wilayah Kerja Puskesmas Mandala dan jika nilai $\mathrm{p}>0,05$ maka Ha ditolak maka tidak ada hubungan pengetahuan dan tindakan tentang gizi dengan kadar albumin ibu hamil penerima BPJS GAKIN di Wilayah Kerja Puskesmas Mandala Medan.

\section{Hasil dan Pembahasan}

\section{A. Gambar Umum Lokasi Penelitian}

Puskesmas Mandala Medan merupakan salah satu puskesmas yang menjadi pusat pembangunan, pembinaan dan pelayanan kesehatan. Puskesmas ini melayani kesehatan masyarakat di empat (4) wilayah kelurahan yaitu Kelurahan Bandar Selamat, Bantan, Bantan Timur dan Kelurahan Tembung. Puskesmas ini mulai dibangun sejak tahun 1970. Adapun ketenagaan di Puskesmas Mandala 
Medan tahun 2014 memiliki tenaga kesehatan yang terdiri dari Tenaga Medis, Paramedis, dan Staff administrasi.

Puskesmas Mandala Medan yang terletak di Jln. Cucak Rawa Kecamatan Medan Tembung ini memiliki batas-batas wilayah sebagai berikut :

- Utara : Sukaramai

- Selatan : Tegal Sari

- Barat : Puskesmas Sentosa Baru

- Timur : Bandar Khalifah Deli Serdang

\section{Karakterisktik Sampel}

\section{Umur}

Rentang kehidupan seseorangyang diukur dengan bulan maupun tahun disebut dengan umur (usia). Pada penelitian ini Ibu hamil penerima BPJS GAKIN yang dijadikan sampel adalah Ibu hamil berumur 20-35 tahun. Distribusi sampel berdasarkan kelompok umur dapat dilihat pada gambar 1 dibawah ini :

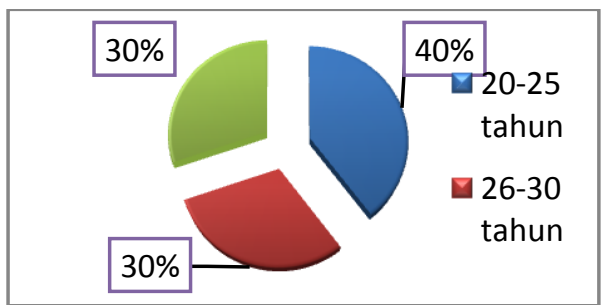

\section{Gambar 1. Distribusi Sampel Berdasarkan Pengelompokan Umur}

Dari gambar 1 diatas menunjukkan bahwa presentase usia ibu hamil paling banyak berada pada kelompok umur 20-25 tahun sebesar $40 \%$. Hal ini menunjukan bahwa ibu hamil memiliki usia yang ideal untuk hamil dan mempunyai anak. Usia ideal untuk seorang wanita mengalami proseskehamilan berkisar usia tersebut diatas, sehingga diharapkan memiiki kesiapan mental dalam menghadapi proses kehamilan. Ibu hamil yang sudah siap secara fisik maupun psikis biasanya akan berupaya mencari tahu hal-hal yang membantu proses kehamilan serta persalinan berjalan dengan normal. Keadaan ini dapat dipengaruhi oleh faktor usia seorang ibu (Sudarti,2010).

\section{Pendidikan}

Pendidikan adalah suatu proses belajar yang direncanakan oleh pendidik untuk mempengaruhi sasaran didik baik individu, kelompok, masyarakat guna mencapai perubahan prilaku. Pendidikan dapat diperoleh melalui dua cara yaitu secara formal maupun informal (Notoadmodjo, 2007 dalam Liow 2012). Distribusi sampel berdasarkan tingkat pendidikan dapat dilihat pada gambar 2 berikut ini :

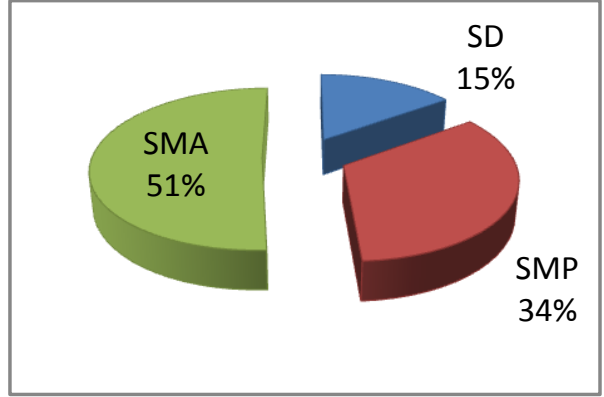

\section{Gambar 2. Distribusi sampel berdasarkan tingkat pendidikan}

Gambar 2 diatas menunjukkan bahwa sebahagian besar sampel mempunyai latar belakang pendidikan SMA sebesar $51 \%$. Pendidikan dapat mempengaruhi proses perilaku seseorang termasuk pengetahuan serta tindakan seseorang.

Hal ini sejalan dengan pendapat dalam beberapa literatur bahwa pendidikan adalah suatu proses belajar yang berarti dalam pendidikan itu terjadi proses pertumbuhan, perkembangan atau perubahan kearah lebih baik, semakin tinggi tingkat pendidikan seseorang maka semakin tinggi juga ilmu pengetahuan yang dimilikinya (Sigalingging, 2009).

\section{Paritas}

Banyaknya frekuensi melahirkan anak yang dialami oleh seorang wanita selama hidupnya, biasanya didalam dunia kedokteran disebut dengan paritas. Distribusi sampel berdasarkan paritas dapat dilihat pada gambar 3 berikut ini:

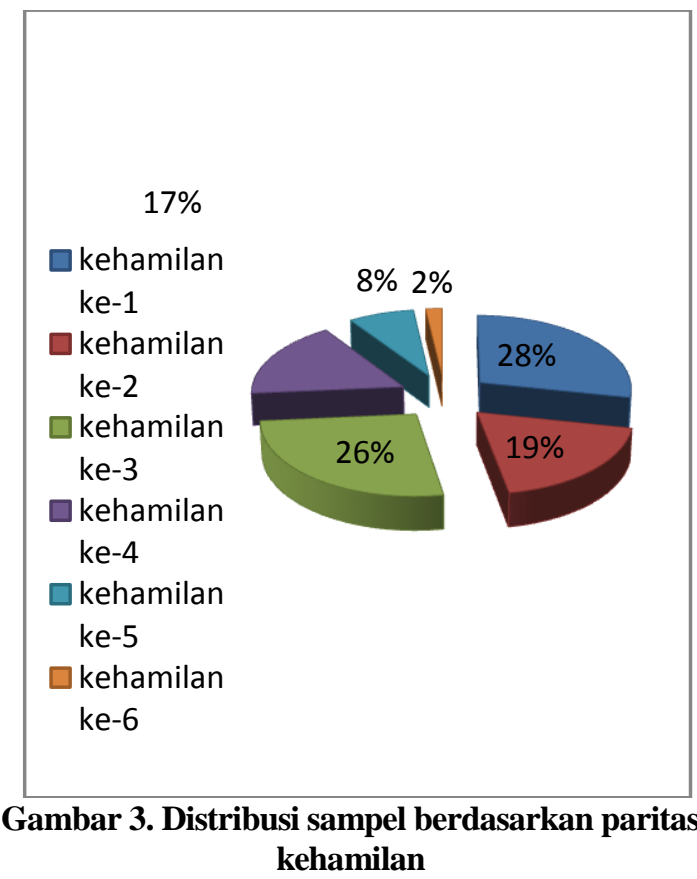

Gambar 3 diatas menunjukkan bahwasanyamasih didapati ibu hamil dengan paritas kehamilan > 3 kali yaitu sebanyak 26,41 \%. Kedaaan seperti ini dapat membahayakan ibu dan janin yang dikandungnya, karena menurut Khotijah (2011) dikatakan bahwa paritas lebih 
dari tiga mempunyai risiko besar untuk terjadinya perdarahan pasca persalinan karena pada multipara otot uterus sering diregangkan sehingga dindingnya menipis dan kontraksinya menjadi lebih lemah. Risiko untuk terjadinya perdarahan pasca persalinan akan menjadi empat kali lebih besar pada yang paritasnya $>3$ kali.

\section{Pengetahuan Gizi}

Pengetahuan adalah salah satu hasil dari "tahu" dan terjadi setelah melakukan penginderaan terhadap objek tertentu. Sebagian besar pengetahuan manusia diperoleh melalui pendidikan, pengalaman, orang lain, media massa dan lingkungan (Notoatmodjo, 2006). Data pengetahuan tentang gizi dikumpulkan dengan cara wawancara menggunakan form kuesioner pengetahuan. Distribusi sampel berdasarkan pengetahuan dapat dilihat pada tabel dibawah ini :

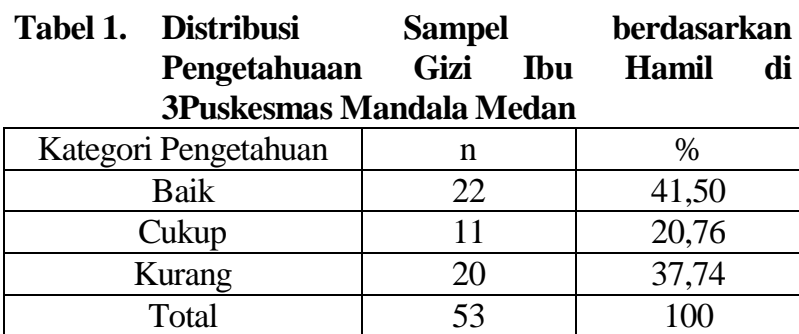

Dari tabel 1 diatas dapat diketahui bahwa kategori pengetahuan gizi ibu hamil di Puskesmas Mandala sebagian besar memiliki kategori baik yaitu sebesar $41,50 \%$. Pengetahuan ibu hamil akan gizi pada masa kehamilan sangat mempengaruhi tindakan ibu dalam memenuhi kebutuhan asupan gizi janin dalam kandungan. Memiliki pengetahuan yang baik tentang nutrisi selama kehamilan diharapkan ibu hamil mempunyai pemahaman yang baik dan mampu mengatasi masalah kehamilan dengan tepat (Agustina, 2013).

\section{Tindakan}

Tindakan merupakan hal penting yang dapat membuat seseorang menjadi lebih baik dalam segala hal serta dapat diamati. Faktor - faktor yang dapat mempengaruhi tindakan seseorang adalah lingkungan, sosial budaya, pengaruh orang lain yang dianggap penting dan pengaruh media massa (Notoatmodjo, 2006).

Data tindakan dikumpulkan dengan wawancara menggunakan form kuesioner tindakan serta diperkuat dengan adanya pengamatan langsung dengan mengisi form pengamat tindakan. Distribusi sampel berdasarkan tindakan dapat dilihat pada tabel dibawah ini :

Tabel 2. Distribusi Sampel berdasarkan Tindakan Ibu Hamil di Puskesmas Mandala Medan

\begin{tabular}{|c|c|c|}
\hline Kategori Tindakan & $\mathrm{n}$ & $\%$ \\
\hline Baik & 19 & 35,85 \\
\hline *Cukup & 19 & 35,85 \\
\hline *Kurang & 15 & 28,30 \\
\hline Total & 53 & 100 \\
\hline
\end{tabular}

Tabel 2 diatas menunujukkan bahwa kategori tindakan ibu hamil di Puskesmas Mandala sudah sebagian besar berada pada kategori baik dan cukup yaitu sebesar
38,85\%. Menurut Bahar (2013) munculnya tindakan sadar gizi didukung oleh adanya pengetahuan gizi ibu hamil yang baik serta motivasi dan niat yang kuat dari diri sendiri sehingga ibu hamil akan berbuat sesuatu untuk memenuhi asupan zat gizi dan kesehatan selama masa kehamilan.

\section{Albumin Darah}

Data kadar albumin darah diperoleh dengan melakukan pengambilan darah sampel melalui jarum suntik yang ditusukkan kedalam pembuluh darah dibagian lengan dengan menggunakan metode Brom Cresol Green (BCG) dengan alat spektrofotometri. Distribusi frekuensi kadar albumin ibu hamil dapat dilihat pada tabel di bawah ini :

Tabel 3. Distribusi Sampel berdasarkan Kadar Albumin

\begin{tabular}{|c|c|c|}
\hline Kategori Albumin & $\mathrm{n}$ & $\%$ \\
\hline Normal & 32 & 60,38 \\
\hline Tidak Normal & 21 & 39,62 \\
\hline Total & 53 & 100 \\
\hline
\end{tabular}

Tabel 3 diatas dapat dilihat bahwa persentase dengan kategori albumin normal sebanyak 60,38\% dan hanya sekitar 39,62 \% yang mempunyai kadar albumin tidak normal.

Menurut Bahar (2013) pada kehamilan terdapat penurunan kadar albumin, terutama selama trimester ketiga. Proses ini disebabkan oleh peningkatan kebutuhan protein dan penggunaannya oleh janin. Rendahnya kadar albumin darah selama masa kehamilan dikhawatirkan dapat memicu terjadinya masalah KEK yang dapat membahayakan perkembangan janin dalam kandungan

\section{Hubungan Pengetahuan Gizi dengan Kadar Albumin}

Tingkat pengetahuan seseorang mempengaruhi perilaku individu, semakin tinggi pengetahuan gizi seseorang semakin tinggi kesadaran untuk mengonsumsi makanan sesuai kebutuhan zat gizinya. Hubungan pengetahuan gizi dengan albumin dapat dilihat pada tabel 4 dibawah ini.:

Tabel 4. Hubungan Pengetahuan Gizi dengan Kadar Albumin Ibu Hamil di Puskesmas Mandala Medan

\begin{tabular}{|c|c|c|c|c|c|}
\hline \multirow{3}{*}{$\begin{array}{c}\text { Kategori } \\
\text { Pengetahuan }\end{array}$} & \multicolumn{4}{|c|}{ Kategori Albumin } & \multirow{3}{*}{$\begin{array}{c}\mathbf{P} \\
\text { Value }\end{array}$} \\
\hline & \multicolumn{2}{|c|}{ Normal } & \multicolumn{2}{|c|}{ Tidak Normal } & \\
\hline & $\mathrm{n}$ & $\%$ & $\mathrm{n}$ & $\%$ & \\
\hline Baik & 18 & 81,82 & 4 & 18,18 & 0,016 \\
\hline *Cukup & 11 & 100 & 0 & 0 & \\
\hline *Kurang & 3 & 15 & 17 & 85 & \\
\hline
\end{tabular}

Ket : $:$ pada saat uji statistik digabung

Dari tabel 4 diatas menunjukkan bahwa pengetahuan gizi yang cukup sebesar $100 \%$ yang memiliki kadar albumin normal sementara pengetahuan gizi yang kurang menyebabkan rendahnya kadar albumin ibu hamil sebesar 85\%. Hasil uji statistik menggunakan Uji Chi Square diperoleh nilai $\mathrm{p}=0,016<0,05$ artinya ada hubungan antara pengetahuan gizi dengan kadar albumin. 
Hal ini sejalan dengan yang dikemukakan Mulyati (2007) bahwa pengetahuan yang dimiliki oleh ibu hamil tentang gizi terutama protein, dapat membantu ibu hamil dan kandungannya terjaga dengan baik serta sehat. Pengetahuan seseorang dalam hal pemilihan jenis makanan serta jumlahnya untuk dikonsumsi selama kehamilan sehingga dapat memenuhi kebutuhan gizi yang diperlukan selama kehamilan.

Pengetahuan yang baik tentang nutrisi kehamilan diharapkan ibu hamil mempunyai pemahaman yang baik dan mampu mengatasi masalah dengan tepat tentang permasalahan kesehatan sehingga dapat menyusun rencana kegiatan yang tepat dan mengevaluasi keadaan dalam kehamilan (Agustina, 2013).

\section{Hubungan Tindakan dengan Kadar Albumin}

Tindakan merupakan aplikasi langsung ibu hamil dalam mengkonsumsi makanan selama masa kehamilan dan sangat berpengaruh terhadap asupan zat-zat gizi yang masuk kedalam tubuh. Hubungan tindakan dengan kadar albumin ibu hamil dapat dilihat pada tabel di bawah ini :

Tabel 5. Hubungan Tindakan dengan Kadar Albumin Ibu Hamil di Puskesmas Mandala Medan

\begin{tabular}{cccccc}
\hline \multirow{2}{*}{ Kategori } & \multicolumn{3}{c}{ Kategori Albumin } & \multirow{2}{*}{ P } \\
\cline { 2 - 4 } Tindakan & \multicolumn{2}{c}{ Normal } & \multicolumn{2}{c}{ Tidak Normal } & Value \\
\cline { 2 - 4 } & $\mathrm{n}$ & $\%$ & $\mathrm{n}$ & $\%$ & \\
\hline Baik & 16 & 84,21 & 3 & 15,79 & 0,016 \\
*Cukup & 15 & 78,94 & 4 & 21,06 & \\
*Kurang & 1 & 6,67 & 14 & 93,33 & \\
\hline
\end{tabular}

Ket : * pada saat uji statistik digabung

Dari tabel 5 diatas menunjukkan bahwa semakin baik tindakan ibu hamil dalam hal gizi, maka semakin normal pula kadar albumin, yaitu sebesar $\quad 84,21 \%$ yang memiliki kadar albumin normal, sedangkan dengan tindakan gizi yang kurang menyebabkan rendahnya kadar albumin ibu hamil sebesar 93,33\%. Hasil uji statistik menggunakan Uji Chi Square diperoleh nilai $\mathrm{p}=0,016<$ 0,05 artinya ada hubungan antara tindakan gizi dengan kadar albumin.

Hal ini sesuai dengan penelitian yang dilakukan oleh Hanafi (2012) mengenai tindakan untuk mengkonsumsi makanan yang tinggi zat gizi terutama protein dapatmemperbaiki status gizi dalam hal ini albumin. Tingginya albumin dalam darah, sangat berpengaruh pada pertumbuhan janin. Dalam tubuh asupan zat gizi terutama protein akan dirubah menjadi albumin dihati.

Albumin merupakan bagian dari protein yang dibutuhkan selama kehamilan berfungsi untuk membawa sari-sari makanan melalui plasenta, untuk perkembangan janin serta bermanfaat dalam pembentukan jaringan sel baru. Selain itu albumin juga sangat berhubungan dengan terjadinya resiko preeklamsi terutama ibu hamil trimester III, bila didapati albumin darahnya dalam konsentrasi rendah (Rossi, 2013).

Keadaan ini diperkuat oleh penelitian Desi (2015) yang juga meneliti variabel lain dalam penelitian ini, menyatakan bahwa dijumpai asupan protein dengan kategori baik (77\%) dan lebih (23\%).

\section{Kesimpulan}

1. Pengetahuan ibu hamil tentang gizi sebagian besar berkategori baik, yaitu $41,50 \%$.

2. Tindakan ibu hamil tentang gizi sebagian besar berkategori baik dan cukup yaitu masing-masing sebesar 35,85\%.

3. Kadar albumin darah ibu hamil sebagian besar dalam kategori normal yaitu sebesar 60,38\%.

4. Ada hubungan yang signifikan antara pengetahuan tentang gizi dengan kadar albumin pada ibu hamil penerima BPJS GAKIN di Wilayah Kerja Puskesmas Mandala.

5. Ada hubungan yang signifikan antara tindakan tentang gizi dengan kadar albumin pada ibu hamil penerima BPJS GAKIN di Wiayah Kerja Puskesmas Mandala.

\section{Saran}

1. Perlu adanya peningkatan pengetahuan ibu hamil melalui penyuluhan dan konseling mengenai nutrisi selama kehamilan.

2. Ibu hamil diharapkan dapat membuka diri dalam menerima semua informasi yang telah diperoleh sehingga dapat menambah pengetahuan yang dapat diaplikasikan dalam kehidupan sehari-hari.

\section{Daftar Pustaka}

Adriani, Merryana dan Bambang Wirjatmadi. 2012. Peranan Gizi Dalam Siklus Kehidupan. Jakarta.

Almatsier, Sunita. 2011.PrinsipDasarIlmuGizi. PT.Gramedia PustakaUtama,Jakarta.

Arisman. 2007. Gizi Dalam Daur Kehidupan. EGC. Jakarta.

Chandra, Budiman.2008. Metodologi Penelitian Kesehatan. EGC. Jakarta.

Elsa, Vicki dan Herdini Widyaning Pertiwi. 2012. Hubungan Paritas Ibu Hamil Trimester 1 dengan Kejadian Emesis Gravidum di Puskesmas Teras. Volume 4, Nomor 2. Jurnal kebidanan, Jawa Timur.

Haryani, Bunda Ira. 2014. Program Diet Ibu Hamil. Cakrawala. Yogyakarta.

Khamzah, Siti Nur. 2014. Pantangan Keras Ibu Hamil. Flashboks. Yogyakarta.

Khotijah, Tri Anasari, dan Amik Khosidah. 2011. Hubungan Usia dan Paritas dengan Kejadian Retensio Plasenta Pada Ibu Bersalin. Volume 5 No 1. Jurnal Ilmiah Kebidanan. Purwokerto.

Komariyah, Siti. 2008. Hubungan Pengetahuan Sikap dan Perilaku Ibu Hamil tentang Pemeriksaan Kehamilan dengan Kunjungan Pemeriksaan Kehamilan di Wilayah Kerja Puskesmas Sukorame Mojoroto Kediri. Tesis. Program Studi Kedokteran Keluarga, Program Pascasarjana, Universitas Sebelas Maret, Surakarta.

Kurniawati, Diny dan Masruroh. 2012. Hubungan Pengetahuan Ibu Hamil tentang Ketidaknyamanan Kehamilan dengan Sikap 
dalam Mengatasi Ketidaknyamanan Kehamilan di Puskesmas Tulis 1 Kecamatan Tulis Kabupaten Batang. Jurnal ilmiah kesehatan akbid uniska, Kendal.

Kurniasih, Dedeh, Hilman Hilmansyah, Marfuah Panji Astuti dan Saeful Imam. 2010. Sehat dan Bugar Berkat Gizi Seimbang. PT Penerbitan Sarana Bobo. Jakarta.

Liow, Fifi M, Nova H. Kapantow, dan Nancy Malonda. 2012. Hubungan Antara Status Sosial Ekonomi dengan Anemia Pada Ibu Hamil di Desa Sapa Kecamatan Tenga Kabupaten Minahasa Selatan. Jurnal Kesehatan Masyarakat. Manado.

Menkokesra, 2012. Pedoman Perencanaan Program Gerakan Nasional Sadar Gizi Dalam Rangka Seribu Hari Pertama Kehidupan (Gerakan 1000 HPK). Republik Indonesia. Jakarta.

Miyata, Siti Misaroh Ibrahim dan Atikah Proverawati. 2010. Nutrisi Janin dan Ibu Hamil. Nuhamedika. Yogyakarta.

Nugroho, Matheus. 2013. Uji Biologis Ekstrak Kasar dan Isolat Albumin Ikan Gabus Terhadap Berat Badan dan Kadar Albumin Tikus Mencit. Volume 5 Nomor 1. Jurnal Teknologi Pangan. Pasuruan.

Rahmaniar, Andi, Nurpudji A. Taslim, dan Burhanudin Bahar. 2013. Faktor-Faktor yang Berhubungan dengan Kekurangan Energi Kronis Pada Ibu Hamildi Tampa Padang Kabupaten Mamuju, Sulawesi Barat. Volume 2, Nomor 2. Media Gizi Masyarakat Indonesia. Makasar.
RK, Murray, Granner DK, dan Rodwell VW. 2009. Biokimia Harper Edisi 27. EGC. Jakarta.

Siagian, Albiner. 2010. Epidemiologi Gizi. Erlangga. Jakarta.

Sigalingging, Ganda. 2009. Pengaruh Tingkat Pengetahuan Ibu Hamil Tentang Gizi Pada Ibu Hamil di Klinik Bersalin SAM Medan. Jurnal Keperawatan, Universitas Darma Agung, Medan.

Sudarti dan Afroh Fauziah. 2010. Hubungan Tingkat Pengetahuan Ibu Hamil tentang ANC dengan Frekuensi Kunjungan ANC di BPS Fajar Samiati, Yogoyudan, Wates, Kulon Progo, Yogyakarta. Jurnal Kebidanan. Yogyakarta.

Supariasa, I Dewa Nyoman, Bachyar Bakri dan dan Ibnu Fajar. 2008. Penilaian Status Gizi. EGC. Jakarta.

Ulinuha, Fuzna Elsa. 2014. Kepuasan Pasien BPJS (Badan Penyelenggara Jaminan Sosial) terhadap Pelayanan di Unit Rawat Jalan (URJ) Rumah Sakit Permata Medika Semarang. Universitas Diponegoro. Semarang.

Utami, Tri Irianti Wira. 2013. Hubungan Pengetahuan dan Sikap Orangtua Tentang Kesehatan Reproduksi dengan Tindakan Orangtua Mengawinkan Puterinya di Usia Remaja. Skripsi Program Studi Promosi Kesehatan dan Ilmu Perilaku, Fakultas Ilmu Kesehatan Masyarakat Universitas Jember, Jember. 